ljtihad, Jurnal Wacana Hukum Islam dan Kemanusiaan

Vol. 16, No. 2 (2016), pp. 237-255, doi : 10.18326/ijtihad.v16i2.237-255

\title{
Fatwa klausul sanksi dalam akad: studi komparatif fatwa Dewan Syariah Nasional (DSN) Majelis Ulama Indonesia (MUI) dan Majma' Fiqh Organisasi Konferensi Islam (OKI)
}

\author{
Zawawi \\ Sekolah Tinggi Agama Islam Negeri (STAIN) Pekalongan \\ E-mail: zawawi.abdulwabid@gmail.com \\ DOI: 10.18326/ijtihad.v16i2.237-255
}

Delaying obligation payment by the customer to the syariah financial institution in some countries whose moslem as the majority, need solutions. One of them is determining Islamic organization fatwa. International Islamic Fiqh Academy has declared fatwa of retributive condition of prohibition based on the agreement between the bank and the customer, while Sharia Directory of Indonesia permits this. Problem of this research is how the concept of retributive condition in those two organizations is and what method used in determining fatwa of the retributive condition is. This research used qualitative approach based on library research, while type of this research is comparative descriptive by using istislahi approach. The result shows that there is significant difference between fatwa from International Islamic Fiqh Academy and Sharia Directory of Indonesia in determining the kind of contrac, that can accept retributive condition based on International Islamic Fiqh Academy, fine can not be applied in an contrac which causes obligation, such as salam, transaction of installments and qard. Sharia Directory of Indonesia decides that fine clause can be applied to any contrac which causes obligation. Determining fatwa from majma fiqh uses saddu dzariah approach by giving attention to the carefulness norms in consideration of maslahat and mafsadat. On the other side, Sharia Directory of Indonesia uses istislahi method which puts maslahat as the priority, especially for syariah financial organizations.

Menunda-nunda pembayaran yang dilakukan oleh nasabah terhadap Lembaga Keuangan Syariah (LKS) di berbagai Negara berpenduduk mayoritas muslim perlu mendapatkan solusi, diantaranya melalui penetapan fatwa lembaga hukum Islam. Majma' Fiqh-OKI mengeluarkan fatwa larangan klausul sanksi denda atas dasar kesepakatan antara LKS dengan nasabah dan DSN-MUI membolehkannya. 
ljtihad, Jurnal Wacana Hukum Islam dan Kemanusiaan, Volume 16, No. 2, Desember 2016: 237-255

Permasalahan yang dikaji dalam penelitian ini adalah bagaimana konsep klausul sanksi menurut fatwa dua lembaga tersebut dan bagaimana metode penetapan fatwa (istinbat) kedua lembaga tersebut tentang klausul sanksi. Penelitian ini adalah riset kepustakaan (library research) dengan analisis kualitatif. Metode yang digunakan adalah deskriptif-komparatif dengan pendekatan istislahi. Hasil penelitian menunjukan adanya perbedaan mendasar antara fatwa Majma' Fiqh-OKI dan DSN-MUI dalam menentukan jenis akad yang dapat menerima klausul sanksi berupa denda. Keputusan Majma' Fiqh-OKI, penetapan sanksi denda tidak diperkenankan pada akad yang menimbulkan hutang-piutang yaitu salam, jual beli secara angsuran \& qard. Fatwa DSN-MUI menegaskan klausul sanksi denda diperbolehkan pada semua akad yang menimbulkan hutang-piutang. Adapun metode penetapan fatwa (istinbat) Majma' FiqhOKI menggunakan metode saddu al-dhari'ah dengan mengedepankan prinsip kehati-hatian dalam menimbang antara maslahat \& mafsadat. DSN-MUI menggunakan metode istișlạ̣i dengan mengedepankan kemaslahatan terutama bagi pihak Lembaga Keuangan Syariah (LKS).

\section{Keywords: Fatwa; Contrac; Retributive condition; Sharia financial institution}

\section{Pendahuluan}

Menurut hukum perjanjian (akad) dalam Islam, apabila suatu perjanjian (akad) telah memenuhi rukun dan syaratnya, perjanjian tersebut mengikat dan wajib dipenuhi serta berlaku sebagai hukum. Dengan kata lain, perjanjian tersebut menimbulkan akibat hukum yang wajib dipenuhi oleh pihak-pihak yang membuatnya (Anwar, 2007:263). Kewajiban memenuhi akad ini mendapat penegasan kuat dari ayat al-Qur'an, hadis, kaidah hukum Islam dan fatwa ulama (Qs. al-Maidah/5:1). Bila salah satu pihak tidak melaksanakan isi akad atau melaksanakan tetapi tidak sebagaimana mestinya (kealpaan) atau terlambat dalam melaksanakannya sehingga menyebabkan terjadinya kerugian (darar) pada pihak lain, maka pihak pertama menanggung ganti rugi materi (daman) (al-Zaila'i, 1896: IV/110).

Di sektor perbankan Syariah di berbagai Negara berpenduduk mayoritas muslim, muncul fenomena sikap menunda-nunda pembayaran yang dilakukan oleh nasabah terhadap bank Syariah yang memberi dana pembiayaan melalui mekanisme akad tertentu. Akibatnya bank Syariah mengalami kerugian, karena dalam melakukan penagihan bank mengeluarkan biayabiaya diantaranya biaya transportasi dan administrasi. Hal ini membuat pengelola perbankan Syariah merasakan pentingnya pengenaan sanksi ganti rugi atas biaya yang dikeluarkan untuk melakukan penagihan kepada nasabah yang lalai dan nakal (menunda-nunda pembayaran). Dalam rangka mengatasi masalah ini, DSN ikut andil dengan mengeluarkan fatwa No. 17/ DSN-MUI/IX/2000 tentang sanksi atas nasabah mampu yang menunda-nunda pembayaran. 
Fatwa klausul sanksi dalam akad:... (Zawawi)

Pada poin kelima dari fatwa disebutkan "Sanksi dapat berupa denda sejumlah uang yang besarnya ditentukan atas dasar kesepakatan dan dibuat saat akad ditandatangani”. Pernyataan ini menunjukan sebuah klausul/syarat sanksi yang menyertai akad.

Di satu sisi, Lembaga Hukum Islam Internasional (Majma’ Fiqh) di bawah naungan Organisasi Konferensi Islam (OKI) dalam pertemuan kedua belas di Riyadh Arab Saudi tahun 2000 tentang klausul sanksi/penalti (sharatjaza $\bar{\imath})$ memutuskan bahwa persyaratan adanya denda dalam utang-piutang dikarenakan faktor keterlambatan adalah suatu hal terlarang. Begitu juga pembeli dalam akad jual-beli secara angsuran (bay'i bi al-taqsit) atas keterlambatan membayar cicilan dari waktu yang telah ditetapkan, tidak boleh dipaksa untuk membayar tambahan (denda) apapun, baik dengan klausul yang dibuat saat akad berlangsung atau tanpa klausul, karena hal tersebut adalah riba yang diharamkan Syariah (Atiyah, 2007:122).

Dari kedua fatwa tersebut di atas, nampak ada perbedaan pemikiran mengenai klausul sanksi (sharat jazāi). Penelitian yang mengungkap metode penetapan hukum (istinbat) urgen dilakukan guna menganalisis tingkat kekuatan dalil yang menjadi sandaran kedua fatwa tersebut.

Penelitian ini akan mengkaji secara mendalam konsep klausul sanksi (sharatjazaī) menurut fatwa Majma' Fiqh-OKI dan DSN-MUI serta bagaimana metode penetapan hukum (istinbat) Majma' Fiqh-OKI dan DSN-MUI dalam menetapkan fatwa tentang klausul sanksi tersebut. Adapun tujuan penelitian ini adalah untuk memperoleh pengetahuan tentang metode penetapan fatwa dan penjelasan seputar pertimbangan hukum klausul sanksi. Hasil penelitian ini diharapkan dapat memberikan kontribusi terhadap pengayaan temuan dalam studi ekonomi Syari'ah, khususnya kegiatan akad yang berbasis klausul sanksi dalam pandangan hukum Islam.

\section{Studi pustaka dan kerangka teori}

Terdapat beberapa buku dan penelitian seputar klausul penalti (sharat jazai) yang menyertai akad, diantaranya "al-Sharat al-jazaī wa Atharubu fi al- Uqūd al-Mu'asirirab" karya Muhammad bin Abdul Aziz al-Yamani (al-Yamani, 2006). Ia mengeksplorasi sharat jaza $\bar{i}$ dan penerapannya dalam fiqh muamalah kontemporer. Memaparkan teori tentang klausul yang menyertai akad dari berbagai mazhab hukum Islam yaitu mazhab Hanafi, Maliki, Syafi'i, Hanbali, Dhahiri. 
ljtihad, Jurnal Wacana Hukum Islam dan Kemanusiaan, Volume 16, No. 2, Desember 2016: 237-255

Disamping itu mendiskusikan tentang kualifikasi hukum sharat jazai secara panjang lebar dengan berbagai pendekatan. Penelitian ini belum menyentuh keputusan Majma’ Fiqh-OKI dan fatwa DSN-MUI.

Sebelumnya, ada beberapa makalah ilmiah yang diajukan para peneliti pada konferensi Majma' Fiqh ke-12 yang berlangsung pada tanggal 24-29 September 2000, diantaranya adalah al-Sharata al-jazaiwa Mukbtalaf Shuwaribi wa Abkamibi karya Hamdati al-'Ainain (al'Ainain, 2006). Dalam makalahnya penulis lebih memfokuskan pada akibat hukum atas penerapan sharatjazai melalui pendekatan studi komparatif antara Syari'ah dan hukum positif. Menurutnya, konsep klausul sanksi dibangun atas dasar dua hal yang saling berkaitan yaitu kesalahan salah satu pihak dan terjadinya kerugian yang dialami oleh pihak kedua. Sebelum pelaksanaan eksekusi klausul sanksi harus didahului dengan peringatan dari satu pihak kepada pihak kedua untuk melaksanakan kewajibannya tepat pada waktunya. Dan legalitas klausul sanksi tergantung pada legalitas akad itu sendiri, artinya jika akad yang dilangsungkan kedua pihak tidak memenuhi rukun dan syarat yang telah ditentukan dalam hukum muamalah, maka klausul sanksi yang dinyatakan tidak memiliki legalitas hukum Syari'ah.

Al-Sharat al-jazai karya Ali Ahmad al-Salus, dalam tulisannya yang cukup panjang, penulis memaparkan berbagai bentuk dan teori tentang syarat yang menyertai akad menurut ulama mazhab empat: Hanafi, Maliki, Syafi'i dan Hanbali, dengan mengkritik kualitas hadis-hadis yang digunakan sebagai dasar hukum. Kajian-kajian tersebut belum mengungkap fatwa klausul sanksi yang ditetapkan oleh Majma' Fiqh-OKI dan DSN-MUI. Oleh karena itu, diperlukan pembahasan yang lebih komprehensif, tulisan ini akan mencoba mengisi kekurangan tersebut.

Instrumen yang digunakan dalam sistem keuangan syariah ditransformasikan dari model akad-akad muamalah yang dimodifikasi sebagai pengganti instrumen yang digunakan dalam sistem keuangan konvensional, yaitu bunga. Dalam istilah lembaga keuangan, instrumen berkonotasi pada alat sebagai perantara yang mengikat antara lembaga keuangan dengan nasabah terkait hak (reward) dan kewajiban (obligation) keuangan (Abdurrachman, 1991:543).

Istilah instrument dalam hal ini, dapat disandingkan dengan model akad muamalah yang diadaptasi (transformasikan) ke dalam sistem keuangan sehingga menjadi sistem keuangan Syari'ah. Dengan demikian, dapat disejajarkan antara instrument (produk) yang digunakan 
Fatwa klausul sanksi dalam akad:... (Zawawi)

oleh perbankan konvensional dengan akad muamalah yang mendasari lembaga keuangan Syari'ah.

Apapun produk yang dihasilkan perbankan Syari'ah, tidak terlepas dari proses transaksi yang dalam fiqh muamalah dikenal dengan istilah akad dan seluruh akad yang dilakukan memiliki konsekuensi duniawi dan ukhrawi karena dilakukan berdasarkan hukum Islam (Dewi, 2004:100).

Dalam literatur fiqh muamalah, kata akad berkonotasi makna pada kata perjanjian (bahasa Indonesia) dan contract (bahasa Inggris). Ia diambil dari kata al-'aqd (bahasa Arab) yang diderivasi dari kata 'aqada, ya'qidu, 'aqdan, jamaknya adalah al-'uqūd. Secara bahasa al-'aqd bermakna al-rabt (ikatan), al-shadd (pengencangan), al-taqwiyah (penguatan). Jika dikatakan 'aqada al-habl (mengikat tali) maksudnya adalah mengikat tali yang satu dengan yang lain, mengencangkan dan menguatkan ikatannya. Al-'aqd juga dapat bermakna al-'ahd (janji) atau al-mithāq (perjanjian).

Adapun definisi akad sebagai suatu istilah hukum Islam adalah ijāb yang diajukan oleh salah satu pihak dengan qabül dari pihak lain yang menimbulkan akibat hukum pada objek akad (Basya, 1983:49).

Secara umum, dalam hukum muamalah Syari'ah terdapat asas-asas umum yang melandasi penegakan dan pelaksanaan akad, diantaranya adalah asas kebebasan berakad (mabda burriyyah al-ta'áqud). Suatu prinsip hukum yang menyatakan bahwa setiap orang dapat membuat akad jenis apapun tanpa terikat kepada nama-nama yang telah ditentukan dalam teks Syari'ah (nash al-Qur'an dan Hadis), begitu juga kebebasan memasukan klausul apa saja ke dalam akad yang dibuatnya sesuai dengan kepentingannya sejauh tidak berakibat pada terjadinya kontradiksi dengan ketentuan al-Qur'an dan Hadis (Zity, 2008:199). Asas kebebasan berakad ini diformulasikan dalam sebuah kaidah fiqh yang berbunyi:

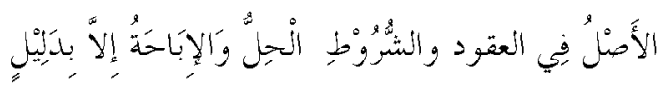

"Hukum asal atas segala bentuk akad dan syarat/klausul yang menyertai akad adalah halal dan mubah kecuali ada dalil yang melarangnya”.

Kaidah tersebut menegaskan bahwa setiap bentuk akad dan syarat itu sah dan boleh selama tidak ada dalil al-Qur'ān, Hadis, Ijma’ atau Qiyas yang melarang akad atau syarat 
ljtihad, Jurnal Wacana Hukum Islam dan Kemanusiaan, Volume 16, No. 2, Desember 2016: 237-255

tersebut. Beberapa ulama berbeda pendapat dalam masalah dalil yang dapat membatalkan atau mengharamkan suatu akad atau transaksi. Imam Ahmad membenarkan bahwa Ijma' dan Qiyas bisa menjadi dasar penetapan syarat dan akad tetapi keduanya tidak bisa dijadikan dasar pembatalan akad tersebut. Hanya nash al-Qur'ān dan Hadis yang menjadi dasar penetapan pembatalan suatu akad, namun mayoritas ulama pendapat bahwa Qiyas dan Ijma' dapat dijadikan bujah dalam membatalkan akad dan syarat (Zuhaili, 1985:IV/201).

Kebebasan membentuk akad dan pernyataan klausul yang menyertai akad tidaklah mutlak, berbagai mazhab hukum Islam mengemukakan beragam teori tentang syarat-syarat penyerta akad, dari yang paling membatasi sampai kepada yang paling liberal, dan teori-teori itu sekaligus menggambarkan luas sempitnya kebebasan berkontrak yang dianut oleh mazhab tersebut. Secara singkat, dapat dikemukakan intisari konsep syarat-syarat yang dibenarkan untuk dimasukan sebagai klausul dalam akad menurut para ulama mazhab sebagai hasil upaya ijtihad, yaitu:

Pertama, syarat yang memperkuat konsekuensi akad. Maksudnya adalah bahwa syarat tersebut merupakan akibat hukum akad sendiri yang ditentukan oleh hukum Syari'ah, sehingga apakah syarat itu dimasukkan atau tidak dimasukkan ke dalam akad sebagai klausul, tidak menambah hal baru dalam isi akad, karena syarat itu adalah konsekuensi akad yang ditetapkan oleh hukum Syari'ah sendiri. Misalnya, seorang pembeli mensyaratkan kepada penjual bahwa apabila terdapat cacat tersembunyi pada barang yang dijual, pembeli mengembalikannya kepada penjual dan menarik kembali pembayaran yang telah dilakukannya (Anwar, 2007:263).

Kedua, syarat yang selaras dengan akad. Yang dimaksud dengan syarat yang selaras dengan akad adalah suatu syarat yang tidak merupakan konsekuensi akad, artinya tidak ditetapkan oleh hukum Syari'ah, melainkan diperjanjikan oleh para pihak berdasarkan kesepakatan dalam rangka memperkuat (menjamin) pelaksanaan akad. Syarat ini dalam hukum Islam meliputi tiga macam, yaitu (1) syarat adanya penanggung dalam akad yang melibatkan utang-piutang, (2) syarat jaminan (adai, ar-rahn), dan (3) syarat hawalah.

Ketiga, syarat yang telah berlaku dalam adat kebiasaan, yaitu syarat yang bukan merupakan konsekuensi akad dan bukan pula merupakan penguat pelaksanaan akad, melainkan syarat yang telah berlaku dalam praktik dan telah biasa diperjanjikan dalam akad oleh masyarakat. Misalnya, seseorang yang membeli peralatan rumah tangga lazimnya mensyaratkan kepada 
Fatwa klausul sanksi dalam akad:... (Zawawi)

penjual agar penjual sekaligus mengantarkan barang tersebut ke rumah pembeli tanpa ongkos tambahan. Hal seperti ini telah lazim diperjanjikan dalam akad.

Keempat, syarat yang mengandung manfaat bagi salah satu dari kedua pihak atau kepada pihak ketiga selama tidak dilarang oleh hukum Syara', tidak bertentangan dengan ketertiban umum dan kesusilaan. Syarat keempat ini menunjuk kepada syarat selain dari yang tiga disebutkan di atas, oleh karena itu, dibatasi tidak bertentangan dengan hukum Syara', ketertiban umum dan kesusilaan.

Dapat disimpulkan bahwa keempat bentuk syarat yang dijelaskan ulama figh tersebut sebagai hasil ijtihad yang bersifat umum, masih menerima beragam persepsi dalam mengimplementasikan pada bentuk-bentuk baru klausul/syarat termasuk klausul yang dirumuskan sebagai upaya preventif menghindari terjadinya kerugian pada salah satu pihak, yang kemudian dikenal dengan istilah sharat jazäi.

Penelitian ini merupakan riset kepustakaan (library research) dengan metode deskriptifkomparatif yaitu memaparkan sejumlah data dan fakta untuk kemudian dianalisis guna mendapatkan kesimpulan yang valid dan dapat dipertanggung-jawabkan. Pendekatan yang digunakan adalah pendekatan istislahi. Adapun sumber data menggunakan sumber sekunder berupa buku, jurnal, majalah, koran, internet, dan sejenisnya yang memuat materi seputar klausul sanksi dalam kajian hukum Islam. Adapun data tersier diperoleh dari kamus, ensiklopedia (mausu'ah), internet dan lain-lain.

\section{Masalah debitur menunda-nunda dan klausul sanksi (sharạt jazaī)}

Masalah penundaan pembayaran hutang oleh debitur telah menjadi pembicaraan para ulama dalam khazanah fiqh Islam. Masalah ini telah muncul sejak dari zaman Nabi saw sendiri. Hal ini dibuktikan dari Hadis yang menegaskan bahwa "Penunda-nundaan pembayaran hutang oleh orang mampu adalah suatu kezaliman”. Begitu juga Hadis yang menyatakan "Penunda-nundaan pembayaran hutang dari orang yang mampu merupakan kezaliman yang menghalalkan pencercaan nama baiknya dan pengenaan bukuman".

Ibnu Mandzur (w.1311) menjelaskan bahwa arti halalnya pencercaan nama baiknya adalah orang itu dapat dinyatakan atau diumumkan buruknya track record pengembalian hutangnya (yasifuhu bi suil-qadha) (Ibnu Mandzur, t.t.VII/171). Sedangkan halalnya pengenaan hukuman 
ljtihad, Jurnal Wacana Hukum Islam dan Kemanusiaan, Volume 16, No. 2, Desember 2016: 237-255

menurut al-Jassas (w.370/981), maksudnya adalah bahwa orang tersebut dapat dikenai sanksi pidana, yaitu berupa penahanan (al-habs). Kemudian al-Jassas menjelaskan lebih lanjut bahwa para ulama telah sepakat bahwa sanksi terhadap pengemplang hutang yang mampu itu adalah penjara dan tidak ada hukuman lain, sepanjang menyangkut hukuman dunia yang dapat dijatuhkan kepadanya selain tahanan. Beliau mengutip sebuah Hadis yang menyebut debitur yang tidak membayar hutang itu dengan kata-kata al-athïr(tawanan) dan penyebutan ini menunjukan bahwa hukuman debitur mampu pengemplang itu adalah penahanan. Adapun pengenaan sanksi denda terhadap debitur pengemplang tidak diperkenankan dalam ajaran Agama Islam sebagaimana dijelaskan para ulama karena dipandang sebagai riba yang diharamkan.

Di era kontemporer, masahal ini muncul kembali menjadi perdebatan di kalangan ulama terutama dalam menjawab problematika Lembaga Keuangan Syariah (LKS). Persoalan ini pertama kali dibahas secara serius pada "Simposium al-Barakah Putaran II" di Tunis pada bulan Nopember 1984. Dalam simposium ini berkembang berbagai pendapat, antara pro dan kontra tentang apa yang disebut dengan klausul sanksi (sharatjazāi) yaitu klausul pengenaan ganti rugi atas debitur ketika tidak memenuhi kewajibannya.

Dalam kajian fiqih muamalah, klausul sanksi (sharat jazāi) atas pihak yang terlambat menjalankan kewajibannya memiliki beragam bentuk, namun sanksi berupa materi (denda sejumlah uang) lebih populer dari bentuk-bentuk sanksi yang lain. Kemudian, denda materi ini dikenal dengan istilah lain al-gharamat at-ta'khiriyah (denda materi atas keterlambatan pembayaran) atau ta'widl (ganti rugi).

\section{Fatwa Majma' Fiqh-OKI no. 109 (3/12)}

Lembaga Hukum Islam International (Majma Figh-OKI) dalam pertemuan ke-12 di Riyadh tanggal 23-28 September 2000 memutuskan fatwa tentang sharat jazai sebagai berikut (Athiyah, 2007: 122):

a. Sharat jaza $\bar{i}$ adalah kesepakatan antara dua pihak yang berakad atas penetapan sanksi denda yang dikenakan pada salah satu pihak atas keterlambatan menunaikan kewajibannya pada waktu yang telah ditentukan sebagai pengganti kerugian pihak yang lain.

b. Sharat jaza $\bar{i}$ atas keterlambatan penyerahan barang dalam transaksi akad salam tidak dibolehkan, karena hakikat akad salam adalah utang. Sharat jazaī pada akad istishna' 
Fatwa klausul sanksi dalam akad:... (Zawawi)

dibolehkan, selama tidak terjadi kondisi tak terelakkan (force majeure). Adapun akad bay'i bi al-taqsit (jual beli dengan angsuran) ketika pembeli (nasabah) terlambat membayar angsuran, pihak penjual (bank) tidak diperbolehkan mengenakan denda kepada pihak pembeli (nasabah), baik melalui kesepakan klausul saat akad ditandatangani atau tanpa klausul, karena hal tersebut adalah riba yang haram.

c. Klausul sanksi (sharatjazaī) dapat dinyatakan pada waktu akad ditandatangani dan dapat pula dinyatakan setelah berlangsungnya akad, sebelum terjadi kerugian.

\section{Dasar hukum}

Dalil-dalil yang dikemukakan oleh fatwa Majma Fiqh ini meliputi ayat al-Qur'an (Q.S. 2: 275, 280), Hadis-Hadis tentang keterikatan orang muslim dengan klausul yang mereka perjanjikan selagi klausul tersebut tidak merubah suatu hukum haram atau halal yang telah ditetapkan Syari'ah dan keterangan para ulama dalam khazanah fiqh mazhab.

\section{Analisis metode fatwa Majma' Fiqh-OKI}

Jika diperhatikan, Majma' Fiqh-OKI dalam menetapkan fatwa larangan penetapan sanksi denda menggunakan metode; Pertama, Menggunakan dilalah 'am surat al-Baqarah ayat 275 "dan Allah telah menghalalkan jual beli dan mengharamkan riba", bahwa penetapan denda materi terhadap nasabah yang menunda-nunda pembayaran hutangnya merupakan bentuk riba yang diharamkan Syari'ah.

Kedua, Menggunakan dilalah 'am surat al-Baqarah ayat 280 "dan jika (orangyang berbutang itu) dalam kesukaran, maka berilah tangguh sampai dia berkelapangan. Dan menyedekahkan (sebagian atau semua utang) itu, lebih baik bagimu, jika kamu mengetabui”. Bahwa pihak debitur yang terlambat membayar hutangnya harus diberi perpanjangan waktu agar dapat bekerja dan mendapatkan hasil untuk membayar hutangnya.

Ketiga, Menggunakan dilalah 'am dari Hadis riwayat Tirmizi dari 'Amr bin 'Auf

$$
\text { المسفمون ثلى شرو طهم إلا شر طا حرم حلالا أو أحل حر امـا. }
$$

"Kaum muslimin terikat dengan syarat-syarat mereka kecuali syarat yang mengharamkan yang halal atau menghalalkan yang haram”. Bahwa pada dasarnya setiap orang diberi kebebasan menyatakan klausul dalam akad dan harus komitmen terhadap klausul tersebut, namun 
ljtihad, Jurnal Wacana Hukum Islam dan Kemanusiaan, Volume 16, No. 2, Desember 2016: 237-255

keabsahan klausul dibatasi dengan satu hal yaitu tidak menghalalkan sesuatu yang haram atau mengharamkan sesuatu yang halal. Sedangkan kesepakatan kedua belah pihak dalam menentukan denda atas keterlambatan pembayaran hutang merupakan klausul yang bertentangan dengan ketentuan al-Qur'an dan Hadis, sehingga klausul tersebut terlarang dan tidak sah.

Keempat, Menggunakan metode qawli yaitu merujuk langsung pada bunyi teks penjelasan ulama dalam kitab fiqh mazhab diantaranya: (1). Al-Jassas menyatakan: tidak ada perbedaan pendapat ulama tentang hukum suatu kasus ketika seseorang yang berhutang sejumlah uang dan telah jatuh tempo kemudian ia berkata kepada pihak yang memberi hutang (kreditur): berilah perpanjangan waktu pembayaran, saya tambah sejumlah uang/dana, hukumnya adalah haram, penambahan dana karena faktor perpanjangan waktu pembayaran (al-Jassas, t.t.:I/ 467). (2). Imam Nawawi menyatakan: setiap akad qard yang membawa manfaat hukumnya haram, apabila disyaratkan dalam akad tersebut (Nawawi, 1985:IV/24). (3). Imam as-Shan'ani menyatakan: akad qard harus memenuhi beberapa ketentuan, diantaranya adalah tidak membawa manfaat kepada pihak kreditur, sesungguhnya segala bentuk manfaat yang dinyatakan sebagai syarat/klausul dalam akad menyerupai riba, karena adanya penambahan dana atas perpanjangan waktu (al-Kasani, 1967:VII/395). Dari teks-teks ulama mazhab dapat disimpulkan bahwa penetapan sanksi ganti rugi merupakan tambahan dana yang harus ditanggung oleh debitur ketika terjadi keterlambatan pembayaran kewajibannya, penetapan ini dinyatakan dalam akad sebagai syarat/klausul oleh pihak kreditur, tidak ada imbalan yang diraih oleh debitur kecuali perpanjangan waktu pembayaran, olehkarena itu, penetapan sanksi denda tersebut merupakan riba nasiah atau riba jahiliyah yang dilarang dalam al-Qur'an dan Sunnah Nabi.

Kelima, Menggunakan pendekatan sejarah, bahwa pelarangan sanksi denda terhadap pengemplang hutang dibangun atas dasar sejarah, tidak ada seorang ahli hukum Islam, ahli Hadis, Hakim atau Mufti di masa lalu yang mengusulkan denda ganti rugi atas sikap debitur yang menunda-nunda pembayaran hutangnya. Atas dasar itulah, al-Jassas menyatakan bahwa pada dasarnya hukuman untuk debitur mampu yang mengemplang itu tidak ada hukuman lain, sepanjang menyangkut hukuman dunia selain dipenjara. Artinya, tidak ada sanksi dalam bentuk denda / materi atas debitur mampu kecuali sanksi dalam bentuk dipenjara (al-Jassas, t.t.:I/467). 
Fatwa klausul sanksi dalam akad:... (Zawawi)

\section{Fatwa Dewan Syariah Nasional (DSN)-Majlis Ulama Indonesia (MUI)}

Ada tiga fatwa DSN yang berkaitan dengan penetapan denda terhadap nasabah mampu yang menunda-nunda pembayaran hutang. Pertama, fatwa No. 17/DSN-MUI/IX/2000 tentang sanksi atas nasabah mampu yang menunda-nunda pembayaran yang berisi: a). Sanksi yang disebut dalam fatwa ini adalah sanksi yang dikenakan LKS kepada nasabah yang mampu membayar, tetapi menunda-nunda pembayaran dengan disengaja; b). Nasabah yang tidak/ belum mampu membayar disebabkan force majeur tidak boleh dikenakan sanksi; c). Nasabah mampu yang menunda-nunda pembayaran dan/atau tidak mempunyai kemauan dan itikad baik untuk membayar hutangnya boleh dikenakan sanksi; d). Sanksi didasarkan pada prinsip ta'zir, yaitu bertujuan agar nasabah lebih disiplin dalam melaksanakan kewajibannya; e). Sanksi dapat berupa denda sejumlah uang yang besarnya ditentukan atas dasar kesepakatan dan dibuat saat akad ditandatangani; f). Dana yang berasal dari denda diperuntukkan sebagai dana sosial.

Kedua, fatwa No. 19/DSN-MUI/IV/2001 Tentang al-qard, dalam hal sanksi disebutkan: a). Dalam hal nasabah tidak menunjukkan keinginan mengembalikan sebagian atau seluruh kewajibannnya dan bukan karena ketidak-mampuannya, LKS dapat menjatuhkan sanksi kepada nasabah; b). Sanksi yang dijatuhkan kepada nasabah sebagaimana dimaksud butir 1 dapat berupa -dan tidak terbatas pada_-penjualan barang jaminan; c). Jika barang jaminan tidak mencukupi, nasabah tetap harus memenuhi kewajibannya secara penuh.

Ketiga, Fatwa No. 43/DSN-MUI/VIII/2004 Tentang Ganti rugi (ta'widh) dijelaskan bahwa; a). Ganti rugi (ta'widh) hanya boleh dikenakan atas pihak yang dengan sengaja atau karena kelalaian melakukan sesuatu yang menyimpang dari ketentuan akad dan menimbulkan kerugian pada pihak lain; b). Kerugian yang dapat dikenakan ta'widh sebagaimana dimaksud dalam ayat 1 adalah kerugian riil yang dapat diperhitungkan dengan jelas; c). Kerugian riil sebagaimana dimaksud ayat 2 adalah biaya-biaya riil yg dikeluarkan dalam rangka penagihan hak yg seharusnya dibayarkan; d). Besar ganti rugi (ta'widh) adalah sesuai dengan nilai kerugian riil (real loss) yang pasti dialami (fixed cost) dalam transaksi tersebut dan bukan kerugian yang diperkirakan akan terjadi (potential loss) karena adanya peluang yang hilang (opportunity loss atau al-furshah al-dha-i'ah); e). Ganti rugi (ta'widh) hanya boleh dikenakan pada transaksi (akad) yang menimbulkan utang piutang (dain), seperti salam, istisnā' serta murabahah dan ijarah; f). 
ljtihad, Jurnal Wacana Hukum Islam dan Kemanusiaan, Volume 16, No. 2, Desember 2016: 237-255

Dalam akad Mudharabah dan Musyarakah, ganti rugi hanya boleh dikenakan oleh shahibul mal atau salah satu pihak dalam musyarakah apabila bagian keuntungannya sudah jelas tetapi tidak dibayarkan. Kemudian pada ketentuan khusus disebutkan: a). Ganti rugi yang diterima dalam transaksi di LKS dapat diakui sebagai hak (pendapatan) bagi pihak yang menerimanya; b). Jumlah ganti rugi besarnya harus tetap sesuai dengan kerugian riil dan tata cara pembayarannya tergantung kesepakatan para pihak; c). Besarnya ganti rugi ini tidak boleh dicantumkan dalam akad.

\section{Dasar hukum dan pertimbangan fatwa}

Dalil-dalil yang dikemukakan oleh fatwa DSN ini meliputi ayat al-Qur'an (Q.S. 5: 1), HadisHadis yang menyatakan perbuatan menunda-nunda pembayaran hutang sebagai perbuatan zalim, dan kaidah-kaidah hukum Islam (al-qawaid al-fighiyah) yang melarang perbuatan merugikan. Beberapa faktor yang dijadikan pertimbangan DSN-MUI dalam memutuskan fatwa di atas adalah : a). bahwa masyarakat memerlukan pembiayaan dari Lembaga Keuangan Syari'ah (LKS) berdasarkan pada prinsip jual beli maupun akad lain yang pembayarannya kepada LKS dilakukan secara angsuran; b). bahwa nasabah mampu terkadang menundanunda kewajiban pembayaran, baik dalam akad jual beli maupun akad yang lain, pada waktu yang telah ditentukan berdasarkan kesepakatan di antara kedua belah pihak; c). bahwa masyarakat, dalam hal ini pihak LKS, meminta fatwa kepada DSN tentang tindakan atau sanksi apakah yang dapat dilakukan terhadap nasabah mampu yang menunda-nunda pembayaran tersebut menurut syari'ah Islam; d). bahwa oleh karena itu, DSN perlu menetapkan fatwa tentang sanksi atas nasabah mampu yang menunda-nunda pembayaran menurut prinsip syari'ah Islam, untuk dijadikan pedoman oleh LKS.

\section{Analisis metode fatwa DSN-MUI}

Pertama, menggunakan dilalah 'àm surat al-Maidah, ayat 1: "Hai orang-orang yang beriman, penubilah aqad-aqad itu". Bahwa setiap orang yang telah terjalin ikatan akad dengan pihak lain -termasuk nasabah dengan perbankan Syariah - berkewajiban menjalankan segala akibat hukum dari akad tersebut pada waktunya tanpa menunda-nunda.

Kedua, Menggunakan dilalab 'am dari Hadis riwayat Muslim, "Dari Abu Hurairah, babwa Rasulullah saw. bersabda: menunda-nunda pembayaran butang bagiyang mampu adalah kez̧haliman, dan 
Fatwa klausul sanksi dalam akad:... (Zawawi)

jika piutang salah seorang dari kalian dialibkan kepada orang yang kaya, maka terimalab”. Bahwa sikap orang kaya lagi mampu menunda-nunda pembayaran hutang yang telah jatuh tempo hukumnya haram karena perbuatan itu termasuk kezhaliman. Dan melunasi hutang hukumnya wajib meskipun pihak pemberi hutang (kreditur) orang kaya. Status sebagai orang kaya bukanlah alasan untuk menunda-nunda pembayaran haknya (al-Hilali, 2006:341),

Ketiga, Menggunakan dilalah '-am dari Hadis riwayat Muslim "Dari Abu Hurairah dari Nabi saw. tentang seorang (pedagang) yang jatuh miskin (bangkrut), jikea ditemukan padanya barang dagangan dari orang yang pernah menjualnya -dengan penundaan pembayaran-maka ia berhak atas barang dagangan tersebut”. Bahwa orang yang memberi piutang terhadap orang lain berhak mendapatkan kembali hak-haknya secara penuh tanpa mengalami kerugian materi.

Keempat, Menggunakan dilalah 'am dari Hadis riwayat Ibnu Majah "Tidak boleh membahayakan diri sendiri dan tidak boleh pula membahayakan orang lain”. Bahwa orang mampu yang menunda-nunda pembayaran merugikan orang lain, sehingga dinilai layak mendapatkan sanksi denda sebagai ganti rugi pihak yang memberi pembiayaan.

Kelima, Kaidah Fiqh "Pada dasarnya, segala bentuk muamalah boleh dilakukan kecuali ada dalil yang mengharamkannya. Bahwa kegiatan akad dengan menyertakan klausul sanksi denda terhadap nasabah yang mampu dan menunda-nunda pembayaran merupakan bentuk akad yang dibolehkan.

Keenam, Sisi maqashid syariah. Secara eksplisit DSN-MUI menggunakan maqashid syariah sebagai acuan dalam menetapkan fatwa dibolehkannya kesepakatan atas penetapan denda materi. Salah satu upaya dalam mewujudkan maqashid sayriah adalah melalui perlindungan terhadap harta benda. Penunda-nundaan pembayaran hutang oleh nasabah mampu merupakan tindakan yang dapat merugikan pihak Lembaga Keuangan Syari'ah (LKS) karena LKS terhalang menikmati manfaat hartanya selama masa penundaan. Membiarkan tindakan tersebut tanpa sanksi terhadap pelakunya mengakibatkan persamaan antara orang yang jujur komitmen membayar hutang tepat waktu dengan orang zalim yang merugikan orang lain.

Secara ringkas, dapat disimpulkan bahwa DSN-MUI dalam mengeluarkan fatwa tentang penetapan denda ganti rugi menggunakan metode istislahi $i$ yaitu; metode penetapan hukum yang menggunakan pendekatan kemaslahatan. Disamping metode istis $\} l a b\} i$, ada metode lain yang sebenarnya dapat digunakan DSN-MUI sebagai acuan penetapan fatwa tersebut 
ljtihad, Jurnal Wacana Hukum Islam dan Kemanusiaan, Volume 16, No. 2, Desember 2016: 237-255

yaitu metode qiyasi, namun tidak disentuh dalam penyebutan dalil-dalil pada ketiga fatwa tersebut.

Metode qiyasi yang dimaksud adalah analogi (qiyas) perbuatan menunda-nunda pembayaran hutang oleh nasabah, diqiyaskan kepada perbuatan gasab yaitu penguasaan seseorang terhadap harta kekayaan orang lain tanpa izin atau mandat/kuasa. Berdasarkan konsep mazhab Syafi'i dan Hanbali yang memandang manfaat suatu benda memiliki nilai materi (mutaqawnim) sehingga ketika suatu benda digasab seseorang dalam waktu tertentu, ia wajib mengganti kerugian materi yang hilang atas manfaat barang tersebut. Titik kesamaan antara keduanya adalah sama-sama menimbulkan kerugian materi bagi pemilik hak karena ia tidak dapat memanfaatkan haknya selama masa gasab atau penundaan pembayaran hutang (al-Zarqa, 85:89).

Penggunaan metode istislahi oleh DSN-MUI nampak jelas pada fatwa dibolehkannya penetapan denda ganti rugi dengan pertimbangan kemaslahatan pihak Lembaga Keuangan Syari'ah (LKS) agar tidak mengalami kerugian materi atas keterlambatan/penunda-nundaan nasabah mampu dalam membayar hutangnya. Sikap menunda-nunda nasabah mampu dapat mengakibatkan kerugian riil bagi Lembaga Keuangan Syari'ah seperti biaya-biaya yang dikeluarkan untuk melakukan penagihan, kerugian riil ini dapat diganti melalui penetapan denda.

Namun penetapan denda atas dasar kesepakatan kedua belah pihak pada waktu akad ditandatangani perlu dipertimbangkan kembali, mayoritas ahli hukum Islam kontemporer secara tegas melarang praktik tersebut, karena kesepakan kedua belah pihak tersebut dinilai akan membuka jalan terjadinya praktik riba terselubung, walaupun LKS tidak menikmati denda tersebut -denda diterimakan kepada pihak ketiga/menjadi dana sosial- namun dinilai sebagai upaya pembungaan uang (pinjamaan berbunga) karena faktor kesepakatan dilakukan pada waktu akad berlangsung.

Mustafa al-Zarqa sebagai salah seorang ahli hukum Islam kontemporer mendukung penetapan denda, namun untuk membedakan antara pengenaan denda terhadap nasabah pengemplang dengan riba yang diharamkan Syari'ah melalui putusan pengadilan yang telah memeriksa perkara dengan mendengarkan keterangan ahli disertai sumpah, bukan melalui kesepakatan antara kedua belah pihak, Pengadilan yang berhak menentukan jumlah denda 
Fatwa klausul sanksi dalam akad:... (Zawawi)

materi sebagai pengganti atas kerugian yang dialami LKS. Adapun Muhammad Darir berpendapat kedua belah pihak dibolehkan melakukan kesepakatan dalam menentukan jumlah denda sebagai ganti rugi atas kerugian riil yang dialami pihak LKS, namun kesepakatan tersebut dilakukan setelah kerugian terjadi, bukan saat akad berlangsung karena menyerupai bentuk riba yang diharamkan oleh Syari'ah (al-Zarqa, 85:87).

\section{Perbandingan fatwa Majma' Fiqh dan DSN}

Fatwa tentang klausul sanksi berupa denda materi dari Majma' Fiqh-OKI dan DSN-MUI memiliki titik temu (kesamaan) dan perbedaan sebagai berikut: latar belakang dikeluarkannya fatwa adalah fenomena nasabah mampu yang menunda-nunda dalam melaksanakan kewajibannya terhadap Lembaga Keuangan Syari'ah (LKS) sehingga LKS mengalami kerugian materi akibat biaya-biaya yang telah dikeluarkan dalam rangka menagih nasabah tersebut. Kedua Lembaga tersebut memiliki kesamaan pandangan bahwa pengenaan denda kepada setiap nasabah atas keterlambatan pembayaran hutangnya kepada Lembaga Keuangan Syari'ah (LKS) tidak diperbolehkan karena dinilai sebagai riba atau jalan menuju riba. Begitu pula kesamaan pandangan tentang kemungkinan penetapan penggantian materi atas kerugian riil yang dialami Lembaga Keuangan Syari'ah akibat sikap nasabah yang menunda-nunda pembayaran hutangnya.

Pada sisi lain, kedua lembaga tersebut berbeda pandangan pada hal dibolehkannya penetapan denda atas penunda-nundaan pembayaran hutang berdasarkan kesepakatan kedua belah pihak pada waktu akad ditandatangani. DSN membolehkan hal tersebut atas nasabah yang mampu dan menunda-nunda pembayaran sedangkan Majma Fiqh secara tegas melarangnya. DSN membatasi penetapan denda bagi nasabah yang mampu, namun tidak menegaskan kriteria nasabah mampu dan nasabah tidak mampu, penegasan ini sangat penting untuk menghindari terjadinya pemberlakuan penetapan denda terhadap seluruh nasabah yang mendapat pembiayaan dari Lembaga Keuangan Syariah (LKS) terutama pada skim qard, salam dan bay'i bi al-taqsit.

Dua fatwa di atas juga memiliki perbedaan mendasar dalam menentukan jenis-jenis akad yang dapat menerima klausul sanksi. Fatwa Majma’ Fiqh-OKI menegaskan klausul sanksi denda hanya bisa diterapkan pada akad yang objeknya melakukan pekerjaan seperti 
ljtihad, Jurnal Wacana Hukum Islam dan Kemanusiaan, Volume 16, No. 2, Desember 2016: 237-255

muqawalah dan istisnā, dan melarang penerapan klausul sanksi denda pada akad yang menimbulkan hutang (dain) seperti akad salam, qard\} dan jual beli murababah dengan angsuran.

Pada akad salam, tidak diperbolehkan menentukan klausul sanksi denda berkenaan dengan keterlambatan dalam penyerahan muslam fih (komoditas salam). Dalam akad qard, LKS tidak diperkenankan menyatakan klausul sanksi denda terhadap nasabah atas keterlambatan pembayaran hutangnya, begitu juga akad jual beli dengan angsuran, pihak penjual tidak diperkenankan menyatakan klausul sanksi denda kepada pembeli ketika terjadi keterlambatan pembayaran angsuran. Sedangkan fatwa DSN membolehkan penerapan syarat sanksi denda pada akad yang menimbulkan hutang (dain) seperti salam, murababah dengan angsuran. Hal ini ditegaskan pada fatwa DSN no.43/2004 poin kelima berbunyi : Ganti rugi hanya boleh dikenakan pada transaksi (akad) yang menimbulkan utang piutang (dain) seperti salam, istis\}na>' serta murababah dan ijarah.

Poin kelima ini menyebutkan akad istisnā' dan ijarah sebagai bagian dari akad yang menimbulkan utang piutang, pernyataan ini perlu dikaji ulang karena dalam kajian fiqh muamalah, akad istisnā' merupakan salah satu akad yang dapat menimbulkan pekerjaan. Begitu juga akad ijarah yang memiliki dua jenis, salah satunya adalah ijarah 'ala al-a'māl (jasa melakukan suatu pekerjaan). Dalam akad istisna sudah dipesan oleh pihak pertama, keterlambatan pihak kedua dalam menyelesaikan pekerjaan tepat pada waktunya dapat mengakibatkan kerugian bagi pihak pertama. Begitu juga akad ijarah/jasa, seseorang yang sudah berjanji untuk menyelesaikan suatu pekerjaan, namun terlambat menyelesaikannya pada jangka waktu yang telah disepakati, dapat mengakibatkan kerugian materi bagi pihak pertama yang menyewa.

Kompensasi yang demikian ini diperbolehkan jika keterlambatannya tidak dikarenakan peristiwa tertentu yang tidak dapat dielakkan (force majeure). Sharatjazăi (klausul sanksi) karena keterlambatan dalam penyerahan objek istisna ' dibolehkan karena fakta bahwa penyelesaian pekerjaan tepat waktu bergantung pada upaya dan komitmen pemanufaktur (penjual), jika tidak mencurahkan waktu dan tenaganya untuk menyelesaikan pekerjaan yang telah dipesan, kemudian menerima kontrak (akad) lain guna mendapatkan lebih banyak pesanan/ keuntungan, ia dapat dikenakan denda atas kerugian yang dialami pihak pemesan. Manfaat klausul sanksi ini bagi pihak pemesan/pembeli untuk menjaga hak-haknya dengan mendapat 
Fatwa klausul sanksi dalam akad:... (Zawawi)

ganti rugi yang diakibatkan penyerahan objek di luar waktu yang telah disepakati (al-Yamani, 2006:320).

Satu hal yang perlu dicermati terkait dana hasil denda dari nasabah yang menundanunda bukan menjadi pendapatan Lembaga Keuangan Syari'ah (LKS), hal ini ditegaskan oleh fatwa DSN nomer 17 tahun 2000, poin keenam berbunyi "dana yang berasal dari denda diperuntukkan sebagai dana sosial", namun dalam fatwa DSN nomer 43 tahun 2004 pada ketentuan khusus disebutkan: ganti rugi yang diterima dalam transaksi di LKS dapat diakui sebagai hak (pendapatan) bagi pihak yang menerimanya. Nampaknya ada kontradiksi antara dua fatwa yang dikeluarkan oleh DSN-MUI terkait dana hasil denda dari nasabah nakal yang sengaja menunda-nunda pembayaran kewajibannya kepada Lembaga Keuangan Syari'ah, apakah menjadi pendapatan bagi LKS atau sebagai dana sosial?

Pada aspek metode Fatwa, ada perbedaan metode fatwa antara kedua lembaga tersebut, yaitu; fatwa DSN mengedepankan metode istislaḥi dengan pertimbangan kemaslahatan Lembaga Keuangan Syariah (LKS). Hal ini dapat dipahami karena metode ini dirasa lebih mudah dipakai dan diterapkan dalam banyak kasus terutama yang menyangkut persoalan muamalah. Sedangkan Majma Fiqh-OKI lebih mengedepankan prinsip kehati-hatian (ibtiya $\bar{a}$ ) dalam mengeluarkan fatwa sehingga menutup berbagai kemungkinan yang dapat membuka pintu terjadinya riba. Prinsip kehati-hatian inilah yang melandasi penggunaan metode saddu al-dhari'ah sebagai salah satu sumber penetapan hukum Islam (Syarifuddin, 2011:II/430). Prinsip kehati-hatian mutlak diperlukan terutama ketika menghadapi benturan antara maslahat dan mafsadat. Apabila maslahat dominan, maka boleh dilakukan dan apabila mafsadat yang dominan, maka harus ditinggalkan. Namun, jika sama-sama kuat, maka untuk menjaga

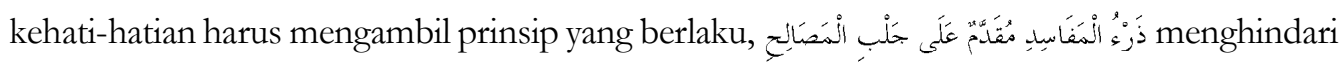
mafsadat lebih diutamakan dari pada meraih kemaslahatan.

\section{Penutup}

Mempertimbangkan kemaslahatan Lembaga Keuangan Syariah (LKS) agar terhindar dari kerugian materi merupakan langkah positif, namun penetapan denda berdasarkan kesepakatan kedua belah pihak saat akad ditandatangani dapat menimbulkan mafsadat yang lebih besar yaitu generalisasi seluruh nasabah yang mendapatkan pembiyaan skim qard dan 
ljtihad, Jurnal Wacana Hukum Islam dan Kemanusiaan, Volume 16, No. 2, Desember 2016: 237-255

murababah dengan angsuran untuk menandatangai akad yang disertai klausul denda atas penundaan pembayaran, hal ini cenderung membawa mafsadat karena pada waktu akad ditandatangani belum dapat dipastikan jumlah kerugian riil yang akan dialami LKS akibat penunda-nundaan nasabah. Untuk menghindari mafsadat terbukanya pintu menuju praktek riba terselubung, sekaligus memperhatikan kepentingan LKS, penentapan denda bagi nasabah mampu yang menunda-nunda pembayaran dilakukan oleh pihak ketiga dan dilakukan setelah terjadi kerugian riil yang dialami oleh LKS. Jika keberadaan pihak ketiga dirasakan sulit terealisasi, penetapan denda dapat dilakukan kedua belah pihak setelah terjadi kerugian riil yang dialami oleh Lembaga Keuangan Syariah (LKS).

Salah satu faktor utama yang mengakibatkan terjadinya perbedaan fatwa tentang klausul sanksi denda atas nasabah mampu adalah adanya nash-nash yang menegaskan keharaman mengambil harta orang lain secara zalim dan nash-nash yang menegaskan kewajiban untuk menghindari kezaliman dan mengenakan sanksi atas orang yang berbuat zalim, ketika terjadi kontradiksi seperti ini, kaidah yang digunakan sebagaimana dijelaskan pakar ushul fiqh adalah mempertimbangkan yang lebih besar kemaslahatannya, dalam hal ini fatwa dibolehkannya pengenaan denda materi atas nasabah mampu yang menunda-nunda pembayaran bersifat kasuistik dengan prosedur tertentu, bukan sebagai konsep hukum yang bersifat umum (bukmun 'àm) yang diimplementasikan atas seluruh nasabah yang mendapatkan pembiayaan dari perbankan Syariah pada skim qard dan murabahah dengan angsuran.

\section{Daftar pustaka}

'Atiyah, 'Atiyah 'Adlan. Mausu'ah al-Qawa'id al-Fiqhiyah. Iskandariyah: Darul Iman, 2007. Al-'Ainain, Hamdati. “al-Sharat al-Jaz̧ai wa Mukbtalaf Shuwaribi wa Abkamibi”, dalam Majalah Majma' Fiqh, Vol. 12 (1426/2006).

Al-Jassas, Abu Bakar ar-Razi. Abkamu al-Qur'an. Kairo: Dar al-Mushaf, t.t.

Al-Nawawi, Muhyiddin. Raudhatu at-Talibin. Beirut: al-Maktab al-Islami, 1985.

Al-Kasani, Alaudin bin Mas'ud. Badai'u al-Sanāi'. Kairo: Matba'ah al-Imam, 1967.

Al-Yamani, Muhammad bin Abdul Aziz. al-Sharat al-Jazaì wa Atharubu fi al-Uqud al-Mu'asbirah.

Disertasi Fakultas Tarbiyah, Universitas Malik Su'ud, Saudi Arabia, 1426/2006.

Al-Zaila'i, 'Uthman bin Ali. Tabyin al-Haqaiq. Kairo: Matba'ah al-amiriyah,1896.

Al-Zuhaili, Wahbah. al-Muamalat al-Maliyat al-Mu'asbirah. Damaskus: Dar al-Fikri, 2008. 
Fatwa klausul sanksi dalam akad:... (Zawawi)

—, al-Fiqh Al-Islamy wa Adilatuhu, Damaskus: Dar el-Fikr, 1985.

Al-Zarqa, Mustafa. Hal Yuqbalu Shar'an al-Hukmu 'ala al-Madin al-Mumätil bi al-Ta'wid 'ala alDain, dalam Majalah Abhats al-Iqtishad al-Islami Vol.2, No.2 (Fakultas Syariah, Universitas Yordan, 1985).

Abdurrachman, Ahmad. Ensiklopedia Ekonomi, Keuangan dan Perdagangan. Jakarta: Pradya Paramita, 1991.

Anwar, Samsul, Studi Hukum Islam Kontemporer, Jakarta: RM Books, 2007.

—, Hukum Perjanjian Syariah, Jakarta: RajaGrafindo Persada, 2007.

Basya, Qadri, Mursyid al-Hairān ila Ma'rifat Ahwal al-Insān. Kairo: Dar al-Furjani, 1403/1983.

Dewi, Gemala. Aspek-aspek Hukum dalam Perbankan dan Perasuransian Syariah di Indonesia. Jakarta: Kencana Prenada Media Group, 2004.

Himpunan Undang-Undang dan Peraturan Pemerintah Tentang Ekonomi Syariah dilengkapi Fatwa DSN MUI Tentang Produk Perbankan Syariah . Yogyakarta: Pustaka Zeedny, 2009.

Ibnu Mandzur. Lisan al-Arab. Bairut: Dar Sadir, t.t.

Syarifuddin, Amir, Ushul Fiqh, Jakarta: Prenada Media Group, 2011.

Zity, Akhtar Abdul Aziz. al-Mu'amalat al-Māliyyat al-Mu'asirat wa Atharu Nažariyatu al-dharai' fi Tatbiqatuba. Damaskus: Dar al-Fikri, 2008. 